\title{
Post/colonial Japanophone versus Global Japanophone
}

Nayoung Aimee KWON ఐna.kwon@duke.edu

In the aftermath of the collapse of Europe's empires, Anglophone, Hispanophone, Francophone, and other such postcolonial literatures emerged as bona fide cultural legacies and fields of inquiry. Robust national and transnational cultural industries of production, from publishing to academia, and increasing consumption of such writings gave recognition to writers and literary works that were subsequently debated throughout the disciplines of world literature at large and postcolonial literature in particular. Postcolonial literatures garnered recognition through such canon-forming venues as literary awards, publications, translations, academic discourses, and so forth. Set beside the abundance of postcolonial literatures from Europe's former empires and the recent rise of Sinophone literature, the glaring yet significant absence of a so-called Japanophone literature in the aftermath of the Japanese empire comes into stark relief. A comparative study of the varying degrees of absence or presence when it comes to such postcolonial revenants can clarify the different degrees of, to borrow Mignolo's terms, "coloniality" (xxi) and "postcoloniality" (xxvii) in the Asia-Pacific and elsewhere ${ }^{1}$.

What might the insignificance, precarity, or outright absence of this discourse tell us about broader blind spots that emerge from the entanglements of postcolonial and post-Cold War dynamics, and of their still little-understood transpacific and interimperial legacies? It is vital to highlight the imperial power dynamics at the center of these literary debates. After all, one does not usually attain the privilege of acquiring a presumably affiliated marginal discourse, such as the Sinophone, Anglophone, or Francophone, without an empire or its (too often nostalgic) specter. All of these

\footnotetext{
1 In my use of the term "coloniality," I am borrowing from Mignolo's work(Mignolo, Walter D. The Darker Side of Western Modernity: Global Futures, Decolonial Options. Duke UP, 2011.) to emphasize the ongoing nature of colonial inequalities in the contemporary world order beyond the historical pastness of officially recognized colonialism. According to Mignolo, there exists a subconscious misrecognition that continues to challenge our ability to recognize the existence of the dynamics of coloniality in the present. While Mignolo points to the problem of the concept of "postcoloniality" within these conditions, I choose to engage with the important strides made within postcolonial studies scholarship as a kindred discourse in tension with and competing against Mignolo's important decolonial project.
} 
labels implicitly presume an untainted center located elsewhere, such as Chinese literature, Spanish literature, English literature, and French literature.

Japanophone literature as a category sounds strange and unfamiliar, though it is not difficult to say what it might signify. Like the terms "Anglophone literature" and "Francophone literature," the term "Japanophone literature" presumes an intimate relationship to the Japanese language, although in some marginal way. Discourses on Anglophone and Francophone literatures have located their colonial and postcolonial linkage at the very center of these language categories, despite still embodying inherent biases and often without fully interrogating race-based assumptions and implicit marginalizations. In Japanophone and, arguably, Sinophone literatures, in contrast, there is a notable marginalization or disavowal of colonial and postcolonial experiences. For example, broader efforts toward reckoning with the colonial past and postcolonial legacies remain incomplete or are made marginal in history books and in public memory. Yet this demotion of the colonial past and its ongoing postcolonial legacies to discursive marginalia in fact offers clues to the largely unacknowledged nature of (post)coloniality, especially in relation to recent global conceptions of culture that tend to delink the past from the present.
In the case of the discourse on Sinophone literature, its belated emergence in the global arena, especially within the US academy, and its speedy reverseimportation from outside China's borders into China has made it one of the most vibrant areas of literary inquiry in studies on so-called Greater China ${ }^{2}$. This development overlaps suggestively with the rise of China after its century of humiliation (1839-1949) vis-à-vis Western and Japanese imperial powers. Rather than taking at face value Sinophone literature's selfproclamation as an unequivocally marginal or counter-hegemonic discourse from below that naturally debunks the rising centrality of China, it behooves us to scrutinize the complex, often unrecognized, and unwitting confluences within such categories, including an imperial or universalist will to power.

At the very least, the possibility of being co-opted for such unintended purposes is worth discussing. Such an awareness of the Sinophone's contested uses does not, of course, simply exclude Sinophone literature's simultaneous capacity to inspire

\footnotetext{
2 The slippery concept of Greater China refers not j ust to the People's Republic but also Hong Kong, Macau, Singapore, Taiwan, as well as diasporic Chi nese communities. See for example in Shih's (Shih, Shu-mei. Introduction to Sinophone Studies : A Cri tical Reader. Columbia UP, 2013, pp.1-16) for mor e on the emergence of this discourse in US acade mia and Shih's introduction to "Visuality and Iden tity" (Shih, Shu-mei. Visuality and Identity : Sinopho ne Articulations Across the Pacific. U of California $\mathrm{P}, 2007$.) for important case studies of the producti on and consumption of Sinophone cultural producti ons including visual media across the Pacific.
} 
critical aspirations in kinship with decolonial projects from other global contexts that seek to critique ongoing imperial power dynamics or the local struggles for recognition of those now situated at China's margins. Yet it is worth noting how and why this strange alignment of the struggles of the metropole and its margins does not adhere to dominant ways of mapping such relations in globally recognized empires like France and England $^{3}$. Here I hope to foster dialogue on the uneasy challenges of disentangling these seemingly contradictory yet coexisting dynamics by putting them into interimperial or transpacific relief.

In the case of Japan, the absence of a broader global discourse on Japanophone literature in relation to empires past and present indicates the self-contradiction and self-division inherent in Japan's identity as an empire. The term "Japanophone" is admittedly an awkward Anglophone translation of a much older (but no less awkward) Japanese-language literature (Nihongo bungaku) and its variations, which emerged at the height of Japan's imperial expansion and assimilation policies and continues through deeply rooted postcolonial legacies. Such categories

3 This seemingly particular predicament of alignment between the metropole and its peripheries, or the colonizers and the colonized, also coexisted in the Japanese empire. More inter-imperial studies of comparable cases in Lussophone, Russophone, and Germanophone literatures are needed. included imperial subject literature (kōmin bungaku); national subject literature (kokumin bungaku); literature of the hinterlands (gaichi bungaku); and regional or peripheral litera- ture (chihō bungaku), to name several.

These variants on colonial-era Japanophone discourse were prevalent throughout Japan's vast imperial landscape and carried different connotations that changed over time. For example, the concept of kokumin bungaku, translated literally as "national subject literature," can also be translated as "national literature"; however, its emergence during the height of Japan's imperial expansions into colonial territories implied a decidedly imperial dynamic that went hand in hand with imperial assimilationist language policies mandating that the colonized be educated to speak and write in Japanese. This is also true of the categories that were territorially inflected, such as chihō bungaku and gaichi bungaku. These names made explicit the peripheral, marginal relationship of these categories of Japanophone literature in colonial territories to a presumed Japanese literature, which was squarely positioned within the metropolitan center of the Japanese archipelago.

However, there is another connotation of Japanophone literature today, what I am calling global Japanophone literature in contrast, which has taken on a much more 
cosmopolitan flair severed from such colonial traces. The fraught legacies of postcolonial literature (in Japan, Taiwan, China, and the divided Koreas, for example) have become further marginalized in this contemporary climate with the emergence of new linguistic experimentations of bilingual cosmopolitan writers who are either ethnically Japanese or EuroAmerican. Authors such as Levy Hideo, Mizumura Minae, and Tawada Yōko not only work predominately in the languages and territories of both Japan and EuroAmerica, but also produce works that are seen as examples of Japanese literature's cosmopolitanism and globalization ${ }^{4}$.

The discursive divide that appears in both global and domestic attention to such writers, despite the difficulty of uniting them under one neat category, is significant because it means critics tend to prioritize Japan's relationship to the world (or the world defined largely as EuroAmerica) at the expense of its inter-Asian

\footnotetext{
4 What I categorize as global Japanophone authors are those writers who write to both Japanese and Euro-American audiences. In the interest of time, I have not examined recent scholarship discussing early Japanese diasporic writings to the Americas here. We might also add Murakami Haruki' s Anglophonic Japanese-language writings and their flexible translatability for the global literary market here. It is widely-known that Murakami' s writings conjure his admiration for American novelists as well as a writing style easily translatable to English. The specter of the colonial and wartime pasts hovering marginally (almost invisibly) in his writings also need to be closely examined.
}

relations. This artificial division creates an illusion that these worlds are somehow separate. As a result, the success or recognition of global Japanophone literature's cosmopolitanism rests on the ongoing failure of critical discourses on globalization to engage with the question of the postcolonial.

The fascinating case of the writer Yokoyama Yu-ta may be a telling example of an exception that proves the rule about this division. Yokoyama does bring an inter-Asian focus through his consideration of traditional and contemporary cultural ties, especially Japan's linguistic connections with China and the contemporary critical discussions about the globalization of Japanese literature. However, he still largely bypasses the (post)colonial question of uncomfortable past legacies. For example, as Takushi Odagiri and Faye Yuan Kleeman discuss, Yokoyama's I Become a Cat (Wagahai wa neko ni naru, 2014), the much-celebrated winner of both the Akutagawa and the Gun-zo literary prizes, is a humorous contemporary play on Natsume So-seki's canonical satire I Am a Cat (Wagahai wa neko de aru, 1905-06).

Told from the perspective of Kakeru, a Japanese-Chinese daburu (mixed blood) youth, Yokoyama's novel follows Kakeru's travels between Shanghai and Tokyo. In doing so, it cleverly recalls the long legacies of Japanese literary and linguistic 
ties to China by setting them in contemporary cultural exchanges ${ }^{5}$. However, the connections Yokoyama traces between So-seki's ruminations on his early travels in England and the contemporary backdrop of contemporary Chinese and Japanese cultural exchanges creates the appearance of an uninterrupted line between the turn of the twentieth century and the turn of the twenty-first century. In this way, the era of Japan's entry into modernity is linked with the contemporary moment of globalization by seemingly bypassing the (post)colonial and Cold War triangulations in between.

The goal here is not to burden any individual author with the impossible feat of comprehensive coverage but rather to recognize and understand the significance of a broader discursive division and hierarchy formed between the global and the (post)colonial. For scholars writing in what may be categorized as the discourse on global Japanophone literature, the central concern is often whether such writers might bring global recognition to Japanese

\footnotetext{
5 I would like to thank Takushi Odagiri, whose invited talk at Duke University in November 2014 (titled "Contemporary Writers of the Japanophone") first introduced me to Yokoyama's works. Odagiri discusses the issue of untranslatability in Yokoyama's works and its relationship to Japanese literature's location in the contemporary era of global English. Kleeman's discussion of the complex hybridity of languages in multiple texts from Japanese literature during a presentation for the Association for Asian Studies in March 2018 situates Yokoyama's works in relation to other Japanophone writings.
}

literature (that is, as being on par with the standards of the West), or whether the Japanese language is conducive to nonJapanese writers writing in Japanese.

Meanwhile, the region's historically long-extant colonial and postcolonial literatures in the Japanese language - that is, (post)colonial Japanophone literatureare separated into a different category, a sort of ethnic ghettoization of the minor within in precarious relation to the glittery global reality of a new Japanophone literature as so-called world or global literature facing outward. The presence of a colonial past and postcolonial present within Japanophone literature represents a broader social issue, a deeply traumatic kernel buried within postcolonial (or post-imperial) and Cold War Japan. It has been actively disavowed since the collapse of the Japanese empire and its subsequent rise, seemingly overnight, as a global power under the American security umbrella $^{6}$. This dizzying turn from enemies to global partners has been discussed by historians elsewhere, although it is still downplayed and little understood in global contexts. In such a climate, the

\footnotetext{
6 See Oguma(Oguma, Eiji. Tan'itsu minzoku shinwa no kigen-"Nihonjin" no Jigazo no Keifu "The Origin of the Myth of Ethnic Homogeneity: The Geneaology of 'Japanese' Self-Images" (Shin' yoōsha, 1995.), especially the introduction, for more on this reverse course, which of course is not unrelated to the United States' own reverse course on foreign policies toward Japan and East Asia during the Cold War.
} 
two separated discourses - those of postcolonial and global Japanophone literature - rarely meet in a genuine manner.

In fact, I would argue that they are positioned as almost mutually exclusive when it comes to Japan's newly projected self-image to the world and to itself in the postwar period. While a global Japanophone discourse projects Japan's image as global and cosmopolitan, in turn allowing the voyage-in of foreign writers via its language, the postcolonial, or Other, Japanophone literature meanwhile conjures uncomfortable memories of contradictory wartime policies that prescribed both identifications with and differentiations from Asian neighbors as so-called brothers. The erasure of the past in which those neighbors who had been reduced to colonized, imperial subjects were then suddenly cast out as persona non grata after the collapse of the Japanese empire created controversial legacies that the nation has not worked throughdomestically, regionally, or globally.

Although they share a linguistic sphere and a past, these incommensurable Japanophone discourses speak to a range of different interests (constituencies, marketing strategies, political affiliations, and so forth). They express quite distinct, perhaps mutually exclusive, imaginaries about Japan's place in the world, in terms of the images they project onto themselves and to outsiders. For example, a recently published book titled Bilingual Japanophone Literature:Between Multilingualism and Multiculturalism (Bailingaru na Nihongo Bungaku: Tagengo tabunka no aida), organizes each chapter around individuals who I have categorized as global Japanophone writers. Yet the author curates only samplings of colonial and postcolonial Japanophone writers in what are reminiscent of Fredric Jameson's allegorical collections (in his oft-critiqued provincialization of so-called Third World literature), in which authors are organized by national origin. This example evidences an internal division within discourse on Japanophone literature. It also gestures to Japanese literature's ambiguous position between the West (former imperial powers) and the East (former colonies), which mirrors Japan's own ambivalent place in the imperial hierarchy of nations past and present - an ambivalence well documented by many scholars within and outside of Japan.

In the present moment, this uneasy transpacific triangulation (of Japan situated between the West and the East) has been muddied further by the region's rapid globalization, which quickly and conveniently enabled the region to forget both its postcolonial and post-Cold War legacies in the name of expediency. The division between the (post)colonial and (post)Cold War periods in the Asia-Pacific may be at 
the heart of the region's collective failure to recognize commonalities and linkages (or entanglements) in the present order of things and their continued spectral hauntings from the past to the present.

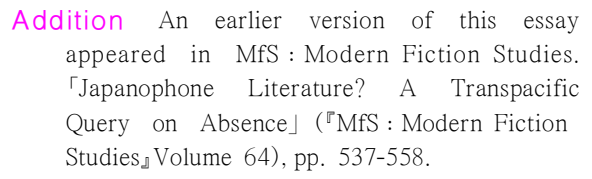

